\title{
ACCA College English Teaching Mode
}

\author{
Renlun Ding \\ Foreign Languages College \\ Zhejiang Gongshang University \\ 18 Xuezheng Street, Xiasha University Town \\ Hangzhou 310018, China \\ E-mail: abcdinge@163.com
}

The research is financed by Zhejiang Gongshang University. No. 200817 Code: 1070 KU208017

\begin{abstract}
This paper elucidates a new college English teaching mode - "ACCA" (Autonomous Cooperative Class-teaching All-round College English Teaching Mode). Integrated theories such as autonomous learning and cooperative learning into one teaching mode, "ACCA", which is being developed and advanced in practice as well, is the achievement of college English teaching reform, this new teaching mode will contribute a lot to the reform of college English teaching.
\end{abstract}

Keywords: "ACCA", English Dormitory, Class-teaching, Autonomous Learning, Cooperative Learning

\section{ACCA College English Teaching Mode}

Base on IEDC (Interaction between English Dormitory and Class-teaching), ACCA is the further development of it. It places more emphases on the collaboration of different departments of the school, which is named all-round in this paper. Since 2001, Zhejiang Gongshang University tried to put IEDC teaching mode into use, after years of trial and experiment, IEDC turned out to be effective and successful in college English teaching, but it needs to be improved, because as IEDC developed, more departments are participated in this teaching mode, this paper is trying to illustrate why a new teaching mode is necessary an $\mathrm{d}$ how it is working especially how to organize departments to establish and ensure its running.

ACCA college English teaching mode first attaches importance to autonomous learning, which in any circumstances is number one thing in learning and teaching. As we know, autonomous learning is a school of education which sees learners as individuals who can and should be autonomous i.e. be responsible for their own learning climate, and it helps students develop their self-consciousness, vision, practicality and freedom of discussion. These attributes serve to aid the student in his/her independent learning. In recent years, the attention and study on research of autonomous learning in China is on the rise, what a school can do first for the students to learn English is offer autonomous learning condition and produce an environment of autonomous learning.

The second element of ACCA is cooperative learning, but first of all, we need to know what cooperative learning is? Cooperative learning is the instructional use of small groups so that students work together to maximize their own and each other's learning. The idea is simple. Class members are organized into small groups after receiving instruction from the teacher. They then work through the assignment until all group members successfully understand and complete it. Cooperative efforts result in participants striving for mutual benefit so that all group members gain from each other's efforts (Your success benefits me and my success benefits you), recognizing that all group members share a common fate (We all sink or swim together here), knowing that one's performance is mutually caused by oneself and one's colleagues (We can not do it without you), and feeling proud and jointly celebrating when a group member is recognized for achievement (We all congratulate you on your accomplishment!). In cooperative learning situations there is a positive interdependence among students' goal attainments; students perceive that they can reach their learning goals if and only if the other students in the learning group also reach their goals (Deutsch, 1962; Johnson \& Johnson, 1989). A team member's success in creating a multi-media presentation on saving the environment, for example, 
depends on both individual effort and the efforts of other group members who contribute needed knowledge, skills, and resources. No one group member will possess all of the information, skills, or resources necessary for the highest possible quality presentation. In IEDC teaching mode, every class is divided into many groups, they study together and take tests together as a group and even they share one same dormitory, that's why IEDC first named English Dorm teaching mode originally.

The second C in ACCA is Class-teaching, which is the center of this teaching mode, because assignments are all designed and given to students in classroom, and all assignments are designed according to teacher's teaching even to catch up or make up classroom teaching. Therefore class-teaching is the bridge and internal part of ACCA teaching mode. Usually it consists of four parts: checking, teaching, stimulating and assigning. It is class-teaching that directs ACCA including autonomous learning and cooperative learning and even the extended learning parts which is influenced or even carried out by other departments in a school, so in other words, class-teaching is the headquarter of this teaching mode, it gives orders, designs the learning procedure, controls the learning process, evaluates the result and grades the participants eventually.

All-round teaching mode is a metaphor, as a narrow description to this teaching mode, actually All-round teaching mode here refers to as many departments as possible is involved in a systematic learning collaborating together in order to promote one learning activity and finally achieve one simple purpose. Learning languages is never easy. Learning in most cases is not a simple learning act conducted by an individual; as a broad meaning, all-round teaching mode here refers to the autonomous management and cooperative work contributing to creating an learning atmosphere so as to promote students' learning which is rarely used in foreign language learning, but as matter of fact, it is of great importance to language learning.

\section{The Grounds for ACCA College English Teaching Mode}

\subsection{IEDC Paves the Way for ACCA in Application}

Interaction between English Dormitory and Class-teaching mode has been in use for years since 2001, the concrete measures or methods conducted by IEDC can be continuously employed by the new teaching mode - ACCA, and could be further strengthened in a more detailed way. That is to say, IEDC lays a solid foundation for ACCA in application.

\subsection{The Advantages of $A, C, C$, and A Itself and Their Integration}

First of all scholars have already proved that autonomous learning is extremely beneficial for language learners. Autonomous learning is the first step to a foreign language learner, and everybody wants to learn and speak in a relatively stress-free environment, which can be dominated by the learner himself or herself, he or she could design what he or she would like to learn and complete in a certain amount of learning period. In other words, he or she could take full advantage of their learning environment and opportunities.

When talking about cooperative learning, we need to know students learning goals. Students' learning goals may be structured to promote cooperative, competitive, or individualistic efforts. In contrast to cooperative situations, competitive situations are ones in which students work against each other to achieve a goal that only one or a few can attain. In competition there is a negative interdependence among goal achievements; students perceive that they can obtain their goals if and only if the other students in the class fail to obtain their goals (Deutsch, 1962; Johnson \& Johnson, 1989). In individualistic learning situations students work alone to accomplish goals unrelated to those of classmates and are evaluated on a criterion-referenced basis. Students' goal achievements are independent; students perceive that the achievement of their learning goals is unrelated to what other students do (Deutsch, 1962, Johnson \& Johnson, 1989). The result is to focus on self-interest and personal success and ignore as irrelevant the successes and failures of others. While cooperative learning emphasizes students must work together in a group to achieve the mutual goal of learning activity and the same result through their joint efforts. To ensure cooperative learning is efficient, the first and most important element in structuring cooperative learning is positive interdependence. If there is no positive interdependence, there is no cooperation. The second basic element of cooperative learning is promotive interaction, preferably face-to-face. Students need to do real work together in which they promote each other's success by sharing resources and helping, supporting, encouraging, and applauding each other's efforts to achieve. The third basic element of cooperative learning is individual and group accountability. The purpose of cooperative learning groups is to make each member a stronger individual in his or her right. Students learn together so that they subsequently can gain greater individual competency. The fourth basic element of cooperative learning is teaching students the required interpersonal and small group skills. The fifth basic element of cooperative learning is group processing. Group processing exists when group members discuss how well they are achieving their goals and maintaining effective working relationships.

Class-teaching is the joint and center of all learning activities which bridges and combines autonomous learning and cooperative learning, to be exact, class-teaching could integrate them into one, taking all advantages they possess of to attain the ultimate goal of teaching, to optimize the teaching effect.

While three-dimension refers to the autonomous teaching promotion and management and cooperative team work 
between different departments of the university including teaching affair department, foreign student's office, logistics department, foreign languages department and other professional departments. How much effectiveness can be enhanced is totally up to how the all-round system working together.

\subsection{Five Components in One Formula by UNESC}

Teaching quality $=($ Students + Teaching material + Teaching method + Environment $)$ Teacher

Above is the formula in language teaching once suggested by UNESC that is to say as for teaching quality, teacher is most important factor, but the other four factors are also significant in teaching or learning language.

As a matter of fact, ACCA pays enough attention to the five factors. For example, ACCA centers on class-teaching, which is directed by teachers based on students' learning efficiency. In classroom teaching, in order to optimize the effect of teaching and learning, teachers often try their best to stimulate students to learn teaching material, both the autonomous and cooperative learning of the individuals and groups and the autonomous and cooperative teaching management of many departments are to create an excellent learning condition, learning atmosphere and learning environment.

\section{The Possible Problems of ACCA College English Teaching Mode in Application}

\subsection{Internal Condition}

It seems that problem may arise due to any factor's change and influence quality of ACCA. ACCA needs the collaboration of departments of a school, so it definitely needs the $100 \%$ support from the school board, the devotion of the president and deans of different faculties, and the totally understanding from the teachers who will carry ACCA out in their teaching and center on ACCAto design their teaching activities thus to optimize their teaching effectiveness. To create an learning environment is not easy especially in a foreign country, most difficult of all, to build a very big mutual foreign learning area is extremely difficult to a school. Suppose at school, English area is rare, library does not quite support ACCA, and native speakers are never available, there is no English Activities such as English Speaking Contest, English teachers are not encouraged to be with students, even there is no English movies, how can ACCAwork, how can students benefit from it? Just as above, among many factors, English teachers are vital part of ACCA, if English teachers do not realize enough the importance of ACCA, how can they implement it especially in class-teaching, thus affected the other factors such the teaching methods they used in class, the teaching material they employed in teaching, and their motivation to students to learn autonomously and cooperatively after class.

\subsection{External Condition}

External condition main refers to the national foreign language teaching policy and the demands of the talents speaking foreign languages. Actually this is not necessary to worry about because with the entry of WTO and the rapid economic development of China, more and more talents who can speak foreign languages are in need. The only point needs to be worried is the designation for instructors is not educators or teachers but workers of teaching. How could a group of laymen produce a sound long-term policy to a school? Worker is a technical implementer, while teacher or educator is someone who has vision and mission to humanize human being (Freire, 1984:19). Gordon (1990: 249-51) characterize school which causes problems to the teachers as follow: firstly, school considers teacher is not its partner, but a subordinate, so when there is conflict, it will be solved by power and authority; secondly, critic is not approved, as the school is always right; thirdly, school has uniformity culture and no heterogeneity; fourthly, school has no responsibility and always blames one to another. Those affect every operational activity in the teaching area including English teaching of ACCA.

\section{Conclusion}

ACCA is a systematic teaching mode, which integrates departments, groups, teachers and students of a school. The integration is to establish one same goal and to attain it with joint effort through creating a big good leaning environment. Language has five functions:" expression, information, exploration, persuasion, entertainment" (Michel, 1967:8-51). Mastering a language means capable in using it with those above functions. And since " language is primarily a social mechanism, languages are learned in social contexts", the more socialized of the learning environment, the much easier will be for learns to learn a foreign language. Only through its practice and further study, could ACCA be rapidly promoted.

\section{References}

Deutsch, M. (1962). Cooperation and trust: Some theoretical notes. In M. R. Jones (Ed.), Nebraska symposium on motivation, 275-319. Lincoln, NE: University of Nebraska Press.

Freire, Paulo. (1984). Pendidikan sebagai Praktek Pembebasan. Jakarta: Gramedia.

Gordon, Thomas. (1990). Guru yang Efektif. Mudjito (adaption). Jakarta: Rajawali Pers.

Johnson, D. W. \& Johnson, R. T. (1989). Cooperation and competition: Theory and research. Edina, MN: Interaction 


\section{Book Company.}

Michel, J. (1967). Foreign Language Teaching. New York: The Mac Millan Company.

Spolsky B. (1989). Condition for Second Language Learning.

Wardhaugh R.V. (1972). Introduction to Linguistics. New York: Mc. Grawn Hill Book Company. 